\title{
Boomjuridischtijdschriften
}

DOI: 10.5553/MvO/2452313520160020506003

\section{Regulering van crowdfundingplatforms: een goede stap in de verkeerde richting}

Het huidige systeem van regulering, het Wijzigingsbesluit financiële markten 2016 en de wenselijkheid van een (meer) toegesneden regelgevend kader

\author{
Mr. J.R.C. Tangelder
}

In deze bijdrage staat de regulering van crowdfunding centraal. Al geruime tijd worstelen wetgever, toezichthouder en marktpartijen met niet voor crowdfunding geschreven wet- en regelgeving. Besproken worden knelpunten in de huidige systematiek en een alternatieve wijze van regulering van de crowdfundingpraktijk.

\section{Inleiding}

Crowdfunding is hot. $\mathrm{Al}$ een aantal jaar is crowdfunding een belangrijk terugkerend onderwerp binnen de politiek, bij marktpartijen, De Nederlandsche Bank (DNB) en de Autoriteit Financiële Markten (AFM). ${ }^{1}$ Steeds meer wordt duidelijk dat crowdfunding een serieus alternatief vormt voor klassieke financieringen, met name voor het midden- en kleinbedrijf. ${ }^{2}$ Uit onderzoek van de AFM blijkt dat binnen Nederland door middel van crowdfunding in 2014 ongeveer EUR 37 miljoen aan financieringen is verstrekt. Dit is een groei van $100 \%$ ten opzichte van $2013 \cdot{ }^{3}$ Uit hetzelfde rapport blijkt de verwachting dat deze groei zich in de aankomende jaren zal voortzetten. Ook in Europees verband is er veel aandacht voor de ontwikkeling van crowdfunding, al ontbreekt een Europees regelgevend kader.

Crowdfunding als relatief nieuwe vorm van financiering zal, gelet op de steeds groter wordende belangen en marktontwikkelingen, een plaats binnen ons financieel toezichtrecht moeten krijgen. Zowel de toezichthouders als de politiek erkennen het belang van crowdfunding en ondersteunen het standpunt dat er een passend systeem van toezichtwetgeving nodig is. Ook zien zij, daarbij gesteund door de literatuur, ${ }^{\mathbf{4}}$ dat de huidige toezichtrechtelijke regels niet toegesneden zijn op de crowdfundingpraktijk, die nog volop in ontwikkeling is. Het Wijzigingsbesluit financiële markten 2016 (hierna: het 
Wijzigingsbesluit ${ }^{5}$ ) zou huidige regelgeving beter moeten laten aansluiten op de crowdfundingpraktijk.

In deze bijdrage zal allereerst kort aan de orde komen welke varianten van crowdfunding er onderscheiden kunnen worden (par. 2). Daarna passeren de verschillende toezichtrechtelijke regimes die op crowdfunding van toepassing (kunnen) zijn de revue en wordt bekeken welke bezwaren en knelpunten deze regimes met zich meebrengen en in hoeverre het Wijzigingsbesluit hier een antwoord op biedt (par. 3). Ten slotte worden de wenselijkheid van en mijn visie op een op crowdfunding toegesneden regelgevend kader besproken (par. 4) en volgt een conclusie (par. 5).

\section{Crowdfunding}

Over het algemeen verloopt een financiering door middel van crowdfunding volgens het volgende proces. Het platform brengt geldgever en geldnemer via het internet bij elkaar. De geldvrager zal via het platform zijn project 'pitchen' bij potentiële geldgevers. Het platform stelt aan de inhoud van de pitch veelal eisen, bijvoorbeeld historische resultaten en prognoses. Voldoet de pitch aan de eisen van het platform, dan wordt het project door het platform aan het publiek bekendgemaakt. Vanaf dit moment kunnen de geldgevers besluiten om al dan niet in het project te investeren. Het platform administreert hoeveel geld er reeds is opgehaald. De geldstromen zelf lopen (veelal) via een stichting derdengelden. Wordt het, van tevoren vastgestelde, minimumbedrag gehaald, dan zal het geld worden overgeboekt aan de geldnemer. Wordt het bedrag niet gehaald, dan zullen de bedragen worden teruggeboekt naar de geldgevers. Het platform ontvangt voor zijn diensten een vergoeding van geldvragers, geldnemers of beiden. Na deze 'matchingsfase' kan een platform ook doorlopende diensten verlenen. Denk hierbij aan het administreren en uitbetalen van rente of dividend aan de geldgevers of het overboeken van aflossingen aan de geldnemer. Het karakteristieke aan deze vorm van financiering is dat op relatief eenvoudige wijze een groot aantal investeerders bereikt kan worden.

Crowdfunding is geen vastomlijnd begrip. Grofweg kennen we de volgende verschijningsvormen: ${ }^{6}$

1. Doneren: hierbij zal de geldgever zijn geld zonder wederprestatie aan de geldnemer doneren.

2. Reward-based: in deze variant zal de geldgever de geldnemer sponsoren. Hiervoor verwacht hij een (niet-financiële) wederprestatie. Hierbij moet worden gedacht aan een rondleiding door een mede door crowdfunding gerealiseerde expositie of een exemplaar van het gesponsorde boek. 
3. Loan-based: in geval van een loan-based crowdfunding leent de geldgever geld uit aan de geldnemer. Hieronder vallen ook obligaties. ${ }^{7}$ De wederprestatie is, zoals gebruikelijk, rentebetaling en uiteindelijke aflossing van het geleende bedrag.

4. Equity-based: dit geldt als een investering in een bedrijf. Er wordt geïnvesteerd door middel van een financieel instrument, met name aandelen. Afhankelijk van het financieel instrument en de resultaten van de geldnemer zal de geldgever dividenduitkeringen ontvangen.

Mengvormen van bovenstaande vier zijn gangbaar. Denk bijvoorbeeld aan een financiering door middel van crowdfunding voor het publiceren van een boek. Heeft de geldgever slechts een klein bedrag over voor het project, dan ontvangt hij geen tegenprestatie en wordt het bedrag gezien als donatie. Komt de geldgever boven een bepaald bedrag, dan ontvangt hij een exemplaar van het boek op het moment dat het boek daadwerkelijk gepubliceerd wordt, waarmee het in de categorie reward-based valt.

Indien en voor zover bovenstaande vormen binnen de bestaande kaders van de financiële toezichtwet- en regelgeving vallen, zal het toezicht op de crowdfundingpraktijk voor een groot deel volgen uit de Wet op het financieel toezicht (Wft) en de daarop gebaseerde regelgeving. Daarnaast moet echter niet worden vergeten dat normen uit de Wet ter voorkoming van witwassen en financieren van terrorisme, Wet op het consumentenkrediet en het Burgerlijk Wetboek van toepassing kunnen zijn. Voor invulling van het geheel van regelgeving zijn ook de interpretaties en beleidsdocumenten van de AFM en DNB van belang. 8

\section{Toezichtrechtelijk kader}

\subsection{Inleiding}

In haar artikel stipt Van Poelgeest ${ }^{\mathbf{9}}$ terecht aan dat bij de beoordeling van de vraag welke toezichtrechtelijke regelgeving van toepassing is op crowdfunding, gekeken moet worden naar de posities van de geldgever, geldnemer en het platform. Met deze posities in het achterhoofd kan worden beoordeeld of een platform, geldnemer of geldgever kan worden aangemerkt als een aanbieder van krediet, een bemiddelaar in krediet, een tussenpersoon met betrekking tot opvorderbare gelden, iemand die opvorderbare gelden aantrekt, een beleggingsonderneming of een beleggingsinstelling. ${ }^{\mathbf{1 0}}$ Zowel door de AFM als in de literatuur is een aantal vergunningen, verbodsbepalingen en ontheffingen hiervan (mogelijk) op crowdfunding van toepassing geacht. In het vervolg van deze paragraaf worden de meest relevante uiteengezet en worden de 
pijnpunten zoals gesignaleerd in de literatuur en door de AFM behandeld. ${ }^{11}$ De aanpassingen die uit het Wijzigingsbesluit voortvloeien, zullen, voor zover relevant voor crowdfunding, ook worden besproken. Doneren en reward-based crowdfunding vallen thans buiten elke Nederlandse financiële toezichtwetgeving. In paragraaf 3.5 zal ik kort aandacht schenken aan deze ongereguleerde vormen. Ik zal in deze bijdrage niet stilstaan bij regels die spelen in het kader van of voortvloeien uit prospectusverplichtingen, antiwitwas- en fraudebeleid, online dienstverlening, fiscale aangelegenheden, het Europees paspoort en algemene voorwaarden.

\subsection{Aantrekken opvorderbare gelden}

Artikel 3:5 Wft bepaalt het volgende:

'Het is een ieder verboden in Nederland in de uitoefening van een bedrijf van het publiek opvorderbare gelden aan te trekken, ter beschikking te verkrijgen of ter beschikking te hebben.'

Waarom is deze verbodsbepaling relevant voor een platform? Een aantal elementen uit deze bepaling is het bespreken waard. ${ }^{\mathbf{1 2}}$ Veel platforms hebben als belangrijk kenmerk dat de gelden die bij de geldgevers worden opgehaald door het platform worden ontvangen en vervolgens worden doorbetaald aan de geldnemers. Bij een onderhandse lening of een lening tegen uitgifte van obligaties (loanbased financiering) zullen deze gelden over het algemeen worden aangemerkt als opvorderbare gelden. ${ }^{\mathbf{1 3}}$ Op een moment dat een geldnemer inderdaad opvorderbare gelden aantrekt, is van belang om te beoordelen of dit in de uitoefening van een beroep of bedrijf gebeurt. Ondanks het ontbreken van een gepubliceerd standpunt hieromtrent lijkt DNB thans het criterium 'in de uitoefening van een beroep of bedrijf' zodanig uit te leggen dat geldnemers die eenmalig via een platform geld aantrekken, dit niet doen in de uitoefening van een beroep of bedrijf. ${ }^{\mathbf{1 4}}$ Niet geheel duidelijk is of dit een juiste interpretatie van dit criterium is. Als we deze interpretatie volgen, zullen veel geldnemers buiten de reikwijdte van artikel 3:5 Wft vallen. Het platform zélf zal in de meeste gevallen ook niet onder het verbod van artikel 3:5 Wft vallen, daar dit de gelden slechts een korte tijd, dat wil zeggen: niet langer dan technisch en organisatorisch noodzakelijk, ${ }^{\mathbf{1 5}}$ onder zich heeft voordat tot doorbetaling aan de geldnemer wordt overgegaan. Belangrijk om hierbij op te merken is dat een platform doorgaans geen krediettransacties voor eigen rekening verricht, of opvorderbare gelden voor eigen rekening aantrekt. ${ }^{\mathbf{1 6}}$ Het platform heeft slechts een faciliterende rol. Van een eventuele overtreding van het verbod tot het uitoefenen van een bankbedrijf, zoals bedoeld in artikel 2:11 Wft, is dus in zijn geheel geen sprake. ${ }^{17}$ 
De logische vervolgvraag is of, als er sprake is van een situatie zoals hierboven uiteengezet, het platform mogelijk in strijd handelt met artikel 4:3 Wft. Artikel 4:3 Wft verbiedt namelijk om '(...) in de uitoefening van een beroep of bedrijf als tussenpersoon werkzaamheden te verrichten ten behoeve van het publiek aantrekken of ter beschikking verkrijgen van opvorderbare gelden'. Als er inderdaad sprake is van toepasselijkheid van deze verbodsbepaling, dan kan hiervoor een ontheffing worden verleend. ${ }^{\mathbf{1 8}}$ Uit zowel het crowdfundingregister van de AFM alsmede het rapport 'Crowdfunding - naar een duurzame sector'19 blijkt dat deze ontheffing een belangrijke en door de AFM veelgebruikte manier is om toezicht op crowdfundingplatforms uit te oefenen. De AFM is van mening dat de werkzaamheden van platforms inderdaad onder het verbod van artikel 4:3 Wft vallen, en dat de platforms daarom een ontheffing van dit verbod nodig hebben. Zoals Van Poelgeest terecht opmerkt, is op deze redenering een en ander aan te merken. Kort gezegd is de ontheffing namelijk gekoppeld aan het verbod van artikel 3:5 Wft. Afgaande op het hierboven gestelde kan ervan uit worden gegaan dat de geldnemers van het platform in de regel niet bedrijfsmatig handelen indien zij slechts eenmalig van crowdfunding gebruik maken en daarom niet onder het verbod van artikel 3:5 Wft vallen. Opmerkelijk is dan ook dat er een ontheffing moet worden verleend voor het bemiddelen in het aantrekken van opvorderbare gelden, terwijl de geldnemers in de meeste gevallen niet onder het 'stamverbod' vallen. Meer voor de hand ligt dat een ontheffing slechts nodig is wanneer de geldnemers de opvorderbare gelden aantrekken in de uitoefening van een beroep of bedrijf.

De AFM ziet dit echter anders, en vereist van platforms die bemiddelen in het aantrekken van opvorderbare gelden, ondanks dat het 'stamverbod' uit artikel 3:5 Wft in de meeste gevallen niet van toepassing is, dat ze een ontheffing in de zin van artikel 4:3 lid $4 \mathrm{Wft}$ verkrijgen. De AFM stelt aan deze ontheffing een aantal eisen, onder meer met betrekking tot de financiële positie van het platform en informatieverstrekking. ${ }^{20}$ Of het stellen van al deze voorwaarden überhaupt binnen de bevoegdheid van de AFM past, is volgens Van Poelgeest geen uitgemaakte zaak, maar zal hier verder onbesproken blijven. ${ }^{\mathbf{2 1}}$ Ten slotte is van belang om op te merken dat in het geval dat het platform een vergunning heeft om te bemiddelen in spaar- en betaalrekeningen, het hem ook is toegestaan om te bemiddelen in het aantrekken van opvorderbare gelden. ${ }^{22}$

Uit het bovenstaande blijkt dat het verbod op het aantrekken van opvorderbare gelden is geïntroduceerd noch later aangepast met het oog op de crowdfundingpraktijk. Daarnaast heeft de AFM in haar rapport van eind 2014 ook een aantal pijnpunten geconstateerd. Allereerst ziet de AFM dat in sommige gevallen geldnemers inderdaad in strijd met het verbod van artikel 3:5 Wft kunnen handelen. ${ }^{\mathbf{2 3}}$ Dit 
acht zij ongewenst, immers: als partijen die geld willen aantrekken via een platform een vergunning nodig hebben voordat zij geld kunnen aantrekken, zal dit een bottleneck zijn voor de verdere ontwikkeling van crowdfunding als volwassen financieringsvorm. Daarnaast acht de AFM het ontheffingsregime voor het bemiddelen in opvorderbare gelden te licht. ${ }^{\mathbf{2 4}}$ De AFM geeft aan dat dit regime bijna geen doorlopende eisen kent, platforms niet aanzet tot professionalisering en onvoldoende transparantie en bescherming voor geldgevers en geldnemers met zich meebrengt. De AFM stuurt daarbij aan op een verzwaring van het ontheffingsregime.

\subsection{Wijzigingsbes/uit}

In het Wijzigingsbesluit adresseert de minister de hierboven geconstateerde problemen ten aanzien van het verbod op het aantrekken van opvorderbare gelden. De minister poogt met een wijziging van het Besluit gedragstoezicht financiële ondernemingen Wft (Bgfo) per 1 april 2016 een oplossing te bieden.

De minister volgt de AFM in haar conclusie ${ }^{\mathbf{2 5}}$ dat het huidige ontheffingsregime te licht is. ${ }^{26}$ De additionele eisen die vanaf 1 april 2016 worden gesteld, zijn er met name op gericht om disfunctioneren van en fraude door een platform te voorkomen. Hierbij moet worden gedacht aan een bedrijfsinrichting die betalingen tussen geldgever en geldnemer garandeert, ondanks dat het platform zelf niet (meer) functioneert. Veiligheid en betrouwbaarheid van ICT-systemen zijn hierbij een belangrijk aspect. De algemene norm uit de Wft met betrekking tot een beheerste en integere bedrijfsvoering zal daarnaast ook van toepassing worden op platforms. ${ }^{27}$ Concreet houdt deze wijziging in dat platforms er zorg voor moeten dragen dat hun personeel betrouwbaar is, dat incidenten geregistreerd worden en dat er een klachtenprocedure openstaat. Daarnaast zal de AFM de beleidsbepalers bij een platform voortaan toetsen op geschiktheid. ${ }^{\mathbf{2 8}}$ Om al deze doelstellingen te bereiken worden artikel 2a, 2b en $2 \mathrm{c}$ toegevoegd aan het Bgfo. Een aantal aspecten van deze artikelen zal ik hier kort behandelen.

Allereerst is het van belang dat deze artikelen slechts op crowdfundingplatforms van toepassing zijn en een beperkte reikwijdte hebben. Om dit te bewerkstelligen werken de genoemde artikelen alleen ten aanzien van ontheffinghouders die 'als tussenpersoon werkzaamheden verrichten ten behoeve van publieksfinanciering'. Publieksfinanciering wordt vervolgens in artikel 2a Bgfo gedefinieerd. Hierin staat dat het moet gaan om '(...) het aantrekken of ter beschikking krijgen van opvorderbare gelden voor een specifiek bestedingsdoel dat voorafgaand aan het publiek is medegedeeld'. Hiermee lijkt voldoende duidelijkheid te zijn geschapen over de reikwijdte van de toegevoegde artikelen. Enig kritiekpunt zou zijn dat 
in de definitie van publieksfinanciering niet is opgenomen dat dit in de uitoefening van een beroep of bedrijf dient te gebeuren voordat het als publieksfinanciering kwalificeert. Het zou wenselijk zijn dit (expliciet) in de definitie op te nemen om meer duidelijkheid te scheppen. ${ }^{\mathbf{2 9}}$

Ten tweede zal er aan geldnemers die gelden verkrijgen door middel van een onderhandse lening of een lening tegen uitgifte van obligaties (loan-based crowdfunding) een vrijstelling worden verleend. Deze vrijstelling is volgens de minister nodig omdat hij, in afwijking van hetgeen hierboven beargumenteerd, ervan uitgaat dat een geldnemer in al deze gevallen onder het verbod van artikel 3:5 Wft valt. ${ }^{30}$ Deze vrijstelling is weer gekoppeld aan het begrip publieksfinanciering. Een voorwaarde voor het verkrijgen van de vrijstelling wordt door deze koppeling dat de geldnemer van tevoren aan het publiek kenbaar moet maken voor welk specifiek doel de gelden bedoeld zijn. Volgens de minister is dit nodig omdat het publiek anders geen inschatting zou kunnen maken van de haalbaarheid van een project. De minister geeft als voorbeeld van zo'n specifiek doel startkapitaal of het openen van een nieuw filiaal. ${ }^{\mathbf{3 1}}$ Mijns inziens is de gedachtegang van de minister logisch, maar is het niet geheel duidelijk hoe het specifieke doel moet worden gedefinieerd. Een rondje langs een aantal crowdfundingplatforms ${ }^{32}$ leert dat het verschaffen van 'werkkapitaal' een veelvoorkomende doelomschrijving van een financiering is. Valt dit onder de definitie van specifiek doel, of is 'werkkapitaal' een dermate generiek doel dat dit niet onder deze definitie valt, waardoor de geldnemer van een financiering met als doel 'werkkapitaal' ook geen vrijstelling kan krijgen van het verbod van artikel 3:5 Wft en dus vergunningsplichtig is? Een nadere invulling van specifiek doel lijkt mij nodig. Zonder nadere invulling wordt voor de geldnemer onnodige onzekerheid gecreëerd over de vraag in welke gevallen hij wel, en in welke gevallen hij geen vergunning nodig heeft.

Ten derde moet worden bedacht wat de consequenties zijn van de opvatting van de minister dat een geldnemer in alle gevallen onder het verbod van artikel 3:5 Wft valt. ${ }^{\mathbf{3 3}}$ Hoewel de minister hiermee het wetssystematische probleem ${ }^{\mathbf{3 4}}$ omtrent de vraag wanneer artikel 3:5 Wft van toepassing is, en hoe dit zich verhoudt tot de ontheffing van artikel 4:3 Wft beantwoordt, brengt deze zienswijze een probleem met zich mee. Deze zienswijze zou namelijk inhouden dat ook onder het huidige recht alle geldvragers in geval van het aantrekken van opvorderbare gelden handelen in strijd met artikel 3:5 Wft. Dit houdt in dat veel geldnemers in overtreding blijven tot het einde van de looptijd van hun financieringen, waarvan tot voor kort werd aangenomen dat ze geen strijd met artikel 3:5 Wft opleverden.

Ten vierde, en zoals reeds in de reacties op de internetconsultatie bij het Wijzigingsbesluit terecht is opgemerkt, sluiten de voorgestelde aanpassingen van het Bgfo nauw aan bij de voorwaarden die de AFM 
thans stelt bij een ontheffing als bedoeld in artikel 4:3 Wft. Doordat daarnaast de voorwaarden voor het verkrijgen van een ontheffing verzwaard zijn en steeds meer aansluiten bij de doorlopende gedragsregels waaraan financiële ondernemingen zich dienen te houden, wordt het vrijstellingsregime feitelijk een verkapte vergunningsplicht. Hiermee dreigt het karakter van de ontheffing te verdwijnen.

Ten slotte is het opmerkelijk dat niet in een overgangsregeling wordt voorzien. 35 Hoewel de voorwaarden die per 1 april 2016 in het Bgfo moeten worden opgenomen sterk overeen zullen komen met de voorwaarden die de AFM thans stelt, geldt dit niet voor de geschiktheidstoets die met het Wijzigingsbesluit geïntroduceerd wordt. Een overgangsperiode die het beleidsbepalers van platforms mogelijk maakt om aan de eisen van de geschiktheidstoets te voldoen, in geval zij daar niet reeds aan voldoen, lijkt me daarom opportuun. Als alternatief kunnen de huidige beleidsbepalers in hun geheel buiten schot van de geschiktheidstoets worden gelaten, waardoor slechts nieuwe beleidsbepalers onder de reikwijdte van de geschiktheidstoets vallen.

\subsection{Aanbieden en bemiddelen consumentenkrediet}

Indien er via crowdfunding krediet wordt verstrekt aan consumenten, is er mogelijkerwijs een vergunning vereist ingeval de kredietaanbieders (in dezen: de geldgevers) handelen in de uitvoering van een beroep of bedrijf. Het krediet wordt doorgaans aangeboden door de geldgever. Deze zal in beginsel niet handelen in de uitoefening van een beroep of bedrijf. Volgens richtlijnen van de AFM handelt een geldgever pas in de uitoefening van een beroep of bedrijf als er voor meer dan EUR 40.000 wordt uitgeleend en er meer dan honderd leningen uitstaan. ${ }^{\mathbf{3 6}}$ Een geldgever kan, ondanks dat deze niet de directe wederpartij is van de geldnemer, maar achteraf de vorderingen van het platform overgedragen krijgt, alsnog als kredietaanbieder kwalificeren. Om dit te voorkomen zal ook nadat de vorderingen zijn overgedragen het beheer en de uitvoering van de overeenkomst moeten geschieden door het platform. ${ }^{37}$ Een vergunningsplicht voor alle geldgevers is precies de gespiegelde situatie van de zojuist in paragraaf 3.2 besproken bottleneck. Ook een vergunningsplicht voor geldgevers kan een strop zijn voor het gebruik en de ontwikkeling van crowdfunding als financieringsvorm. In mijn optiek moet de AFM er binnen het huidige regime daarom naar streven een situatie te creëren waarin voorkomen wordt dat geldgevers vergunningsplichtig worden in gevallen waarin zij financiering verstrekken aan geldvragers door middel van crowdfunding. Dit zou kunnen door zodanige voorwaarden aan 'in de uitoefening van een beroep of bedrijf' te verbinden dat er genoeg ruimte voor (kleine) geldgevers overblijft om zonder vergunning te financieren. 
Net als bij het aantrekken van opvorderbare gelden is ook het bemiddelen bij het aanbieden van consumentenkrediet aan een verbodsbepaling onderhevig. ${ }^{\mathbf{3}}$ Bemiddelen bij het aanbieden van krediet is een breed begrip. Hieronder vallen onder meer activiteiten die gericht zijn op de totstandbrenging van een kredietovereenkomst tussen een bedrijfsmatig handelende aanbieder en consumenten (respectievelijk geldgever en geldnemer) en daarnaast ook het (assisteren bij het) beheer en de uitvoering van deze overeenkomst. Volgens deze interpretatie is in gevallen waarin de geldgevers niet handelen in de uitoefening van een beroep of bedrijf (zoals hierboven uiteengezet), strikt genomen ook geen vergunning nodig voor het bemiddelen bij het aanbieden van consumptief krediet. Het platform voorziet namelijk niet in activiteiten gericht op het tot stand brengen van een overeenkomst tussen een bedrijfsmatig handelende aanbieder en een consument, daar de aanbieder niet in de uitoefening van een beroep of bedrijf handelt. De AFM stelt echter ook op dit punt wel degelijk dat er een vergunning nodig is voor het bemiddelen bij het aanbieden van consumptief krediet, en verbindt hier ook voorwaarden aan. Deze redenering is voor mij wetssystematisch lastig te begrijpen. Vanuit een praktische insteek is het standpunt van de AFM beter te verdedigen. De AFM zal deze vormen van crowdfunding willen reguleren, ook als wet- en regelgeving hier strikt genomen geen ruimte voor bieden. Het alternatief is namelijk dat dit aspect van crowdfunding buiten de reikwijdte van toezichtregelgeving valt. Uiteindelijk verdient een kader van wet- en regelgeving dat past op de crowdfundingpraktijk de voorkeur. Op die manier hoeft de AFM zich niet in lastig te begrijpen bochten te wringen.

De AFM heeft in haar rapport van eind 2014 deze problematiek ook erkend: 'Een extra knelpunt bij bemiddelaars is dat betwijfeld kan worden of er sprake is van "bemiddeling" nu meestal niet bemiddeld wordt voor professionele aanbieders.' Een mogelijke oplossing die de AFM hiervoor geeft, is om bepaalde bemiddelaars als aanbieders te kwalificeren. Volgens artikel 2:6o Wft wordt onder aanbieden namelijk tevens het beheer van overeenkomsten verstaan. Hiervoor zou nodig zijn dat deze aanbieders (het platform) daadwerkelijk wederpartij worden van de geldnemer, aangezien de wetsgeschiedenis van artikel 2:60 Wft uitgaat van de civielrechtelijke definitie van het begrip aanbod. Los van de vraag of hiermee de definitie van aanbieder te sterk opgerekt wordt, doet deze situatie vreemd aan, omdat in de meeste gevallen nou juist het platform 'ertussenuit' valt, en derhalve geen partij meer is van de geldnemer. Ook de spaarzame gevallen waarin het platform geen beheer en uitvoering van de overeenkomst voor zijn rekening neemt, zouden buiten de reikwijdte van de door de AFM aangedragen oplossing vallen. Terecht houdt de AFM bij deze conclusie in haar rapport dan ook een slag om de arm en stelt dat ingeval deze interpretatie niet gevolgd kan worden, er een aanpassing moet komen van wet- en regelgeving. Desondanks is de AFM sinds 
juni 2015 wel deze interpretatie gaan hanteren, waardoor het nu voor een platform in alle gevallen vereist is om een vergunning als kredietaanbieder te hebben. ${ }^{\mathbf{3 9}}$ De door de wetgever aangelegde scheiding tussen bemiddelaar en aanbieder wordt door de interpretatie van de AFM tenietgedaan. ${ }^{40}$

\subsection{Vergunning betaaldienstverlening}

Onder het verlenen van betaaldiensten valt onder meer het uitvoeren van betalingstransacties, daarbij inbegrepen geldovermakingen en geldtransfers. ${ }^{41}$ Voor het verlenen van betaaldiensten is op basis van artikel 2:3a Wft een vergunning vereist. Zoals al eerder aangestipt, is een van de belangrijke werkzaamheden van een platform het verzamelen en uitbetalen van gelden. ${ }^{42}$ Dit lijkt op het eerste gezicht het verlenen van betaaldiensten op te leveren. De spil van deze definitie is echter dat de betaaldiensten als hoofdactiviteit of zelfstandig te identificeren activiteit te kwalificeren moeten zijn. De hoofdactiviteit van een platform is in nagenoeg alle gevallen het bij elkaar brengen van partijen teneinde een financiering te faciliteren. De betaaldienstverlening is hierin niet als hoofdactiviteit of zelfstandige activiteit te zien. Het overboeken van gelden zal in het geval van een platform dan ook niet snel als een betaaldienstverlening kwalificeren en daardoor ook niet vergunningsplichtig zijn. ${ }^{43}$ Van Poelgeest brengt in haar artikel nog wel enige nuance aan wat betaaldienstverlening betreft. Zij geeft aan dat de AFM van platforms verwacht dat zij werken met een stichting derdengelden voor het ontvangen en doorbetalen van gelden. Deze stichting zou als hoofdactiviteit dus wel betaaldiensten verlenen. Van Poelgeest betoogt echter dat een stichting niet 'los' kan worden gezien van het platform, en dat de vraag of er sprake is van een hoofdactiviteit of zelfstandige activiteit moet worden bekeken in het kader van alle activiteiten van een platform. Volgens deze redenering zou ook in geval van een stichting derdengelden geen vergunning vereist zijn. Ten slotte merkt Van Poelgeest op dat naar haar weten er in Nederland geen platforms zijn die een vergunning voor het verlenen van betaaldiensten hebben. De AFM stelt in haar rapport van eind 2014 dat afhankelijk van de inrichting van het platform, het platform onder het bereik van artikel 2:3a Wft kan vallen. Als gemiddeld meer dan EUR 3 miljoen per jaar wordt doorbetaald, dient er volgens de AFM bij DNB een vergunning te worden aangevraagd voor betaaldienstverlening.

Op Europees niveau is er nog geen duidelijkheid over de vraag of dienstverlening van een platform onder betaaldienstverlening valt. Het is onduidelijk of de Directive on Payment Services (PSD) ${ }^{\mathbf{4}}$ op platforms van toepassing is en of, als dit het geval is, die onverkort op alle platforms van toepassing is. Het belangrijkste handvat dat de Europese Commissie hierin geeft, is: '(...) or the Payment Services Directive might apply to crowd lending or investing, depending on the 
circumstances, e.g. the business model used and the amounts raised'. ${ }^{45}$ Werkelijke duidelijkheid is hiermee niet verschaft. Uit een opinie van de European Banking Authority (EBA) blijkt echter dat de activiteiten van platforms in andere lidstaten wél als betaaldienstverlening worden gekwalificeerd. ${ }^{\mathbf{4 6}}$ Waarbij de EBA bovendien heeft geconcludeerd dat de problematiek omtrent betaaldienstverlening '(...) is likely to be present in all types of crowdfunding (donations, rewards, lending, and investment)'.

\subsection{Beleggingsonderneming}

Een platform dat beleggingsdiensten verleent, kan vergunningsplichtig zijn ingevolge artikel 2:96 Wft. De AFM stelt op haar website dat als het mogelijk is via het platform te investeren (bedoeld is waarschijnlijk: beleggen) in ondernemingen door middel van het kopen van verhandelbare aandelen, er sprake is van de aankoop van effecten (financiële instrumenten). De AFM is van oordeel dat de activiteiten die een platform verricht, in ieder geval moeten worden aangemerkt als het ontvangen en doorgeven van orders van geldgevers met betrekking tot die financiële instrumenten (orderremissier). Daarnaast kan sprake zijn van het plaatsen van financiële instrumenten. In die gevallen zal het platform als beleggingsonderneming kwalificeren en zal het in beginsel vergunningsplichtig zijn.

Afgezet tegen bovenstaande drie toezichtrechtelijke regimes lijkt de vergunningsplicht die van toepassing is op een beleggingsonderneming het beste te passen bij de praktijk van crowdfunding. Als we echter naar artikel 168a Bgfo kijken, dan ontstaat bij het toezichtrechtelijke regime dat van toepassing is op de beleggingsonderneming een economisch knelpunt. Artikel 168a Bgfo omvat namelijk een provisieverbod voor beleggingsondernemingen. De ratio achter dit verbod is dat beleggingsondernemingen in de uitvoering van hun werkzaamheden foutieve prikkels zouden kunnen ervaren ingeval zij provisie ontvangen van (enkele) aanbieders van effecten. De AFM constateert echter dat dit in veel gevallen het verdienmodel van een platform raakt, aangezien deze voornamelijk hun omzet halen uit provisie. De oplossing die de AFM aandraagt, is een kwalificatiealternatief van de werkzaamheden van het platform. De AFM zou de activiteiten van het platform willen kwalificeren als de beleggingsdienst van het plaatsen van financiële instrumenten zoals bedoeld in artikel 1:1 Wft (definitie van 'verlenen van een beleggingsdienst' onder f). Hierdoor zou het platform een provisie kunnen ontvangen van de geldvrager voor het plaatsen van de effecten bij de geldgever op initiatief van de geldnemer (zonder plaatsingsgarantie), omdat met deze interpretatie de activiteiten vallen onder de uitzondering op het provisieverbod zoals bedoeld in artikel 168a lid 1 onder c Bgfo. 


\subsection{Wijzigingsbes/uit}

Ook de minister ziet in het provisieverbod van artikel 168a Bgfo een probleem dat opgelost dient te worden. Met het Wijzigingsbesluit poogt hij een oplossing te bieden. De minister erkent dat het provisieverbod een belangrijke inkomstenbron voor platforms is, die niet moet worden geblokkeerd door het provisieverbod. De oplossing die de AFM aandraagt voor dit probleem is niet de lijn die door de minister gevolgd wordt. Mede door een advies van de European Securities and Markets Authority (ESMA), waarin geconcludeerd is dat, in geval van equity-based crowdfunding, platforms over het algemeen beleggingsdiensten verlenen, is de minister tot de conclusie gekomen dat naar huidig recht inderdaad het provisieverbod van artikel 168a Bgfo van toepassing is. ${ }^{47} \mathrm{Om}$ toch een oplossing te bieden voor de problemen die het provisieverbod voor platforms met zich meebrengt, heeft de minister ervoor gekozen om voor deze specifieke situatie een uitzondering op artikel 168a Bgfo te maken.

De minister wil de uitzondering aan voorwaarden onderwerpen om ervoor te zorgen dat slechts platforms onder de uitzondering zullen vallen. Daarnaast benadrukt hij dat het om een sterk in beweging zijnde markt gaat. Latere veranderingen van de voorwaarden mogen dan ook worden verwacht als de markt hiertoe aanleiding geeft. Op dit moment is de minister voornemens de uitzondering te verbinden aan een viertal voorwaarden: ${ }^{48}$

1. De uitzondering geldt alleen voor zover het de volgende beleggingsdienst betreft: 'Het in de uitoefening van een beroep of bedrijf ontvangen en doorgeven van orders van cliënten met betrekking tot financiële instrumenten.'

2. De dienstverlening mag hiernaast alleen zien op aandelen en obligaties of daarmee vergelijkbare waardebewijzen of schuldinstrumenten, rechten van deelneming in een beleggingsinstelling of icbe daaronder niet inbegrepen, die niet worden verhandeld op een gereguleerd handelsplatform zoals een gereglementeerde markt. Typisch zullen de effecten die via een platform worden verhandeld aan deze voorwaarden voldoen. Met deze tweede voorwaarde wordt de uitzondering toegesneden op platforms. Immers, 'normale' beleggingsondernemingen met meer gangbare dienstverlening zien, in tegenstelling tot de dienstverlening van platforms, vaak wel op effecten die op een gereglementeerde markt worden verhandeld.

3. De betrokken effecten moeten worden aangeboden door de geldnemer zelf. Met deze voorwaarde wordt de uitzondering geblokkeerd voor secundaire handel in eenmaal uitgegeven effecten via een platform. Volgens de minister is de 
achterliggende gedachte dat de bemiddelende rol van het platform tussen geldgever en geldnemer in deze situatie in mindere mate aanwezig is. De rol van het platform in deze situatie zou geen ondersteuning meer behoeven door een uitzondering op het provisieverbod. Hoewel dit nu niet direct relevant lijkt, omdat er op dit moment nog geen platform is dat secundaire handel aanbiedt, zal dit in de toekomst waarschijnlijk anders zijn. De AFM heeft in haar toekomstvisie aangegeven te verwachten dat bij een groeiende markt secundaire handel door platforms zal worden aangeboden. ${ }^{49}$ Wellicht zal op dat moment deze voorwaarde opnieuw onder de loep genomen moeten worden.

4. Als een platform gebruik wil maken van de uitzondering op het provisieverbod, moet zij hiervan melding maken bij de AFM. De gedachte achter deze voorwaarde is dat de AFM hierdoor te allen tijde dicht op de crowdfundingmarkt zit. Deze laatste voorwaarde is enigszins vreemd. Immers, op het moment dat een platform een vergunning aanvraagt om als beleggingsonderneming te opereren, zal de AFM in kennis gesteld moeten worden van de beleggingsdiensten die het platform wil gaan aanbieden. Op deze manier heeft de AFM reeds kennis van de activiteiten van het platform, en dus ook van een eventueel gebruik van bovengenoemde vrijstelling. ${ }^{\mathbf{5 0}}$ Indien het zou gaan om een beleggingsonderneming die besluit om na het verkrijgen van de vergunning ook de hierboven bedoelde vorm van crowdfunding aan te gaan bieden zonder een aanvullende aanvraag bij de AFM, dan zou deze beleggingsonderneming in strijd met de haar verleende vergunning handelen.

Als een platform aan al deze voorwaarden voldoet, zal het gewoon provisie kunnen vragen en hier dus ook zijn verdienmodel op inrichten. Bij de voorwaarden die de minister wil gaan stellen, is een belangrijke kanttekening te plaatsen: ondanks dat beoogd wordt de vrijstelling alleen voor platforms te laten gelden, geeft de formulering ruimte voor andere beleggingsondernemingen om van deze vrijstelling gebruik te maken. ${ }^{\mathbf{1}}$

\subsection{Doneren en reward-based}

De crowdfundingvormen 'doneren' en 'reward-based' vallen buiten de Nederlandse toezichtwetgeving. ${ }^{\mathbf{5}}$ Mijns inziens is regulering van deze vormen wel gewenst. Hoewel er in 2014 'slechts' EUR 8.600.000 is gefinancierd door middel van deze varianten, is de gemiddelde groei over de afgelopen jaren wel behoorlijk. Zo is het gemiddelde jaarlijkse groeipercentage van reward-based crowdfunding in Nederland maar liefst 211\%. Doneren (donation-based) volgt op een afstand met een 
nog steeds behoorlijk gemiddeld jaarlijks groeipercentage van $67 \% .53$ Door deze extreme groeipercentages zal het bedrag van EUR 8.60o.ooo de aankomende jaren waarschijnlijk fors gaan stijgen. De financiële belangen worden daarmee dermate groot dat malafide platforms, onjuiste besteding van gelden en onterecht niet-uitgevoerde projecten een serieus probleem kunnen gaan vormen en symbool kunnen gaan staan voor crowdfunding als wildwestfinancieren. Daarnaast moet worden bedacht dat met name niet-professionele partijen geïnteresseerd zijn in deze vormen van crowdfunding. Deze partijen zijn door het, over het algemeen, ontbreken van voldoende kennis en kunde een groep die meer bescherming behoeft dan professionele partijen. Zonder enige vorm van regulering zal het voor niet-professionele partijen moeilijk zijn om te beoordelen of ze veilig(er) via een platform kunnen financieren. Met regulering van donation-based en reward-based crowdfunding kan er voor deze partijen hieromtrent meer zekerheid worden gecreëerd. Deze zekerheid zal vervolgens ook bijdragen aan een verdere groei van crowdfunding. Immers, een niet-professionele partij zal eerder geneigd zijn te financieren als zij weet dat het platform dat zij wil gebruiken gereguleerd is en daarmee een bepaalde mate van stabiliteit en veiligheid bezit, terwijl die neiging minder is in een situatie waarin zij daarvan geen enkele inschatting kan maken. In paragraaf 4 zal worden uiteengezet hoe deze vorm van regulering er mijns inziens uit zou moeten zien.

\section{Toekomst van crowdfunding}

In paragraaf 3 is de huidige stand van crowdfundingregulering en het Wijzigingsbesluit besproken. De huidige wet- en regelgeving blijkt onvoldoende aan te sluiten op de crowdfundingpraktijk. De vraag is echter welke richting gekozen moet worden als het aankomt op de regulering van crowdfunding? In deze paragraaf zal ik tegen de achtergrond van de markt en de wenselijkheid van regulering mijn antwoord geven op de vraag hoe regulering binnen de crowdfundingsector eruit zou moeten zien.

\subsection{Marktontwikkelingen}

De AFM heeft in haar rapport van eind 2014 een aantal (gefundeerde) voorspellingen gedaan over de toekomst van de crowdfundingmarkt. Zo concludeert zij dat de crowdfundingsector op dit moment tussen een startende en een groeiende markt in staat. De AFM gaat er hierbij van uit dat crowdfunding geen kort leven beschoren zal zijn, maar dat crowdfunding here to stay is en zich uiteindelijk zal ontwikkelen tot een volwassen financieringsalternatief. Dit houdt in dat de bedragen die via platforms aangetrokken worden, zullen (blijven) stijgen. Platforms zullen verder professionaliseren. Waar er nu nog een schare aan (kleine) platforms bestaat, is de verwachting dat op termijn 
slechts een aantal grote spelers overblijft. Ook verwacht de AFM dat er op middellange termijn platforms zullen zijn die willen voorzien in een secundaire markt, waarin leningen en/of aandelen verhandeld kunnen worden. Waar geldvragers nu vooral particulieren of midden- en kleinbedrijf zijn, voorziet de AFM dat op termijn ook grotere ondernemingen deze manier van financieren ontdekken. De geldgevers zullen in het kielzog 'meeprofessionaliseren'. Niet alleen (vermogende) particulieren zullen financieringen verstrekken via crowdfunding, maar ook andere professionele investeerders gaan hier hun rendement proberen te halen. Dit vertaalt zich in de volgende percentages: loan-based crowdfunding in Nederland stijgt snel met een gemiddelde jaarlijkse stijging van $257 \% .{ }^{54}$ Equity-based crowdfunding stijgt iets minder hard met een gemiddelde jaarlijkse stijging van 44\%.55, ${ }^{56}$ Deze percentages gecombineerd met de wetenschap dat in 2014 ongeveer EUR 37.000.000 ${ }^{57}$ door middel van crowdfunding is opgehaald, leiden tot de conclusie dat binnen nu en een aantal jaar loan-based en equity-based crowdfunding waarschijnlijk niet meer aangemerkt kunnen worden als een nichemarkt, maar dat crowdfunding geaccepteerd moet worden als een volwassen financieringsalternatief. Om in te schatten waar deze groei in de komende jaren toe leidt, kan een blik geworpen worden op het Verenigd Koninkrijk. Het Verenigd Koninkrijk ligt een aantal jaar voor als het gaat om de groei van de crowdfundingmarkt. Per hoofd van de bevolking wordt er in het Verenigd Koninkrijk 7,8 maal zo veel gefinancierd door middel van crowdfunding als in Nederland. Deze onbetwiste Europese koploper kan dienen ter inspiratie als het gaat om vraagstukken omtrent crowdfunding en is een voorbeeld als het gaat om de economische en maatschappelijke impact die crowdfunding kan hebben.

\subsection{Wenselijkheid van regulering}

Fundamenteel is de vraag wat de meerwaarde is van regulering van crowdfundingplatforms. Voor marktpartijen is het zonder (goede) regulering lastig om samenwerking met platforms te zoeken. Het is voor hen namelijk zeer moeilijk om een inschatting te maken van de betrouwbaarheid en stabiliteit van platforms, als deze niet onder toezicht(recht) vallen. Hoewel regulering uiteraard geen zekerheid geeft dat er met een bonafide partij handel gedreven wordt, draagt de keurmerkfunctie van regulering wel bij aan de mate van zekerheid, en daarmee ook aan de mate van bereidheid waarmee marktpartijen zaken willen doen met platforms. Met name voor banken is dit relevant. Banken zijn gebonden aan tal van voorschriften, denk hierbij aan de bancaire zorgplicht, 'know your customer'-verplichtingen en diverse informatieplichten. Zou een bank willen cofinancieren (een deel van de financiering door crowdfunding, een deel door een reguliere bankfinanciering), dan brengt dit, gelet op eerdergenoemde voorschriften, voor de bank risico's met zich mee. Deze risico's doen 
zich voor bij zowel de geldnemer als de geldgever. Ter illustratie: de klant als geldnemer kan bij zijn bank aankloppen met de vraag of cofinanciering mogelijk is. Het zal moeilijk voor de bank zijn hierover te adviseren, omdat het voor de bank lastig is om in te schatten of en vooral hoe een te gebruiken platform functioneert en wat de specifieke risico's zijn. De klant als geldgever is feitelijk de gespiegelde situatie. In hoeverre moet de bank informeren en acteren als zij merkt dat een klant financiert via crowdfunding, terwijl dit niet passend is bij het profiel van de betreffende klant?

In het verlengde van deze keurmerkfunctie ten aanzien van andere marktpartijen moet ook worden gekeken naar de gevolgen van regulering op de bereidheid van geldnemers en geldvragers. Ook in hun bereidheid om gebruik te maken van crowdfunding is een zekere mate van zekerheid en stabiliteit met betrekking tot de te gebruiken platforms een positieve factor. Voorkomen moet worden dat crowdfunding te boek komt te staan als wildwestfinancieren. Een aantal risicofactoren waarmee geldgever en geldnemer zich geconfronteerd zien:

1. Falen van ICT-systemen: juist omdat crowdfunding zich nagenoeg geheel online afspeelt, heeft een ICT-storing directe en grote gevolgen voor de administratie en geldstromen van lopende projecten.

2. Faillissement van het platform: ook in dit geval kunnen lopende geldstromen in gevaar komen. Doordat het zeer de vraag is of de administratie van een platform na faillissement nog naar behoren zal functioneren, en geldvragers over het algemeen niet weten aan wie zij geld verschuldigd zijn, kan dit de continuïteit van projecten in gevaar brengen.

3. Fraude (door met name de geldvrager en het platform): geldvragers hebben een informatievoordeel ten opzichte van geldgevers, waardoor zij de mogelijkheid hebben om onjuiste informatie te verstrekken of relevante informatie te verzwijgen. Ten aanzien van het platform kan worden gedacht aan het plaatsen van spookprojecten of het onjuist doorbetalen van gelden.

4. Ongunstige contractvoorwaarden: ${ }^{58}$ de voorwaarden van crowdfundingcontracten worden over het algemeen opgesteld door de platforms. Deze zouden in potentie nadelig kunnen zijn voor geldgevers en/of geldnemers.

5. Gebrek aan secundaire markt:59 in geval van equity-based crowdfunding zijn de investeringen in principe verhandelbaar. Er is echter nog geen werkende secundaire markt, waardoor 
geldgevers tot het einde van de looptijd aan hun investering vastzitten.

Behalve het reguleren om de zekerheid en stabiliteit van platforms te waarborgen mogen ook de belangen van geldnemers en geldgevers niet uit het oog worden verloren. Wordt geldgevers wel duidelijk gemaakt dat crowdfunding niet zo veilig is als een spaarrekening en wat de risico's voor hen zijn? ${ }^{\mathbf{6 0}}$ Welke informatie moet aan geldgevers of geldnemers beschikbaar worden gesteld voorafgaand aan het moment van financieren en welke informatie tijdens de looptijd van de financiering? Voorkomen moet worden dat geldgevers investeringen doen die niet passend zijn bij hun financiële positie. Gespiegeld daaraan moet overkreditering van geldnemers worden voorkomen. Duidelijkere regulering kan deze belangen beschermen.

\subsection{Toekomst van crowdfundingregulering}

Gelet op de analyse in paragraaf 3 en het besprokene in deze paragraaf is in mijn visie de huidige regelgeving onvoldoende om risico's juist te adresseren, een groeiende markt en groter wordende belangen te ondersteunen en een doordacht juridisch-technisch kader te bieden. Kortom: de reguleringswens zoals hierboven uiteengezet wordt door de huidige regelgeving niet (juist) vervuld.

Wetssystematisch is er zoals reeds vastgesteld het een en ander aan te merken op de huidige stand van de toezichtrechtelijke behandeling van crowdfundingplatforms in Nederland. Het Wijzigingsbesluit neemt weliswaar een tweetal knelpunten weg, te weten de moeilijk volgbare redenering dat er in geval van loan-based crowdfunding geen sprake is van een vergunningsplicht voor het aantrekken van opvorderbare gelden, maar dat er voor de bemiddeling hiervoor wél een ontheffing vereist is en een uitzondering voor platforms op het provisieverbod voor beleggingsondernemingen, maar laat de markt ook weer met een aantal onduidelijkheden zitten. Het is van belang om te bedenken dat het Wijzigingsbesluit een voortzetting is van een gekunstelde oplossing. De Nederlandse toezichtregelgeving is (nog steeds) niet toegespitst op crowdfundingstructuren. Zo kan een platform als beleggingsonderneming worden gekwalificeerd, terwijl de structuur van een platform geenszins in verband staat met de initiële gedachte van wat een beleggingsonderneming is. ${ }^{\mathbf{6 1}}$ In een onderzoek van de universiteit van Cambridge wordt vastgesteld dat twee van de factoren die geleid hebben tot sterke groei van crowdfunding in het Verenigd Koninkrijk het 'dedicated regulatory regime and a supportive government' zijn. ${ }^{\mathbf{6}}$ In het onderzoek wordt met betrekking tot Nederland gesteld dat 'there is no specific regulation'. Mijns inziens zal er dan ook in Nederland, net als in het Verenigd Koninkrijk, regelgeving moeten worden geïntroduceerd die specifiek is toegesneden op crowdfunding(platforms). Het bijschaven van 
toezichtfiguren die niet voor crowdfunding geschreven zijn, wordt daarbij verlaten. Het argument dat de AFM hiertegen aandraagt, vind ik niet overtuigend. De AFM stelt in haar onderzoek van eind 2014 dat een specifiek op crowdfunding toegesneden regelgevend kader zou leiden tot overregulering van een jonge markt. Een specifiek toegesneden regelgevend kader hoeft echter geen overregulering tot gevolg te hebben, maar zorgt er wel voor dat lastig verklaarbare redeneringen tot het verleden kunnen behoren.

Mijn voorkeur gaat uit naar een systeem waarin er in beginsel slechts één partij aan regulering onderworpen is: het platform. Onder huidige wet- en regelgeving ontstaat in sommige gevallen twijfel of geldnemer en/of geldgever door een vergunningsplicht geplaagd worden. Zoals vastgesteld zou dit de ontwikkeling van crowdfunding kunnen remmen, terwijl het reguleren van geldnemer of geldgever geen meerwaarde kent boven het reguleren van slechts het platform. ${ }^{63} \mathrm{De}$ inrichting van de regulering van platforms zou moeten worden opgehangen aan een aantal definities: die van crowdfunding, maar ook de verschillende vormen daarvan, zoals crowdinvesting (equity-based crowdfunding) en crowdlending (loan-based crowdfunding). ${ }^{64}$ Daarnaast kunnen ook definities van donation-based en rewardbased crowdfunding worden geïntroduceerd. Op deze manier kan aan de aspecten als benoemd in paragraaf 3.7 en 4.2 per definitie precies zoveel gewicht toegekend worden als voor de betreffende variant van crowdfunding nodig is.

Regulering van platforms zou grosso modo op twee aspecten moeten zien: (1) wat zijn de rechten en plichten van het platform jegens geldgever en geldnemer, en (2) hoe moet een platform operationeel en op het gebied van governance ingericht zijn? Ten aanzien van de plichten jegens geldgevers en geldnemers kan hierbij worden gedacht aan een (lichte) vorm van het 'know your customer'-principe als de markt hiertoe aanleiding geeft. Met name aan de geldnemerszijde kan van platforms (op den duur) worden verwacht dat zij bepaalde informatie vergaren. Hierbij kan worden gedacht aan een verplichting voor het platform om inzicht te hebben in de financiële status van de geldnemer of de opbouw van een concernverhouding. Ook bepaalde informatieplichten van het platform ten aanzien van geldgevers of geldnemers liggen voor de hand. Welke informatie het platform moet verstrekken over de structuur van de financiering en de mogelijke risico's zou moeten komen vast te liggen in wet- en regelgeving. Dit hangt direct samen met een verplichting van het platform om deze informatie van de geldvrager te verkrijgen en te controleren op betrouwbaarheid. Ten aanzien van de inrichting van het platform zou aansluiting kunnen worden gezocht bij de voorschriften die thans van toepassing zijn, bijvoorbeeld een geschiktheidstoets van beleidsbepalers, een stabiele ICT-inrichting, gebruik van een stichting derdengelden (zoals thans ook al veelal het geval is), een integere 
beleidsvoering en bepaalde eisen aan de zeggenschapsstructuur. Ook hier geldt: mocht de markt aanleiding geven tot verdere eisen aan de inrichting van het platform, dan kan hier relatief eenvoudig aan tegemoetgekomen worden doordat de toezichthouder in dit verband beleid uitvaardigt zonder daarbij het systeem van regulering geweld aan te doen.

\section{Conclusie}

De regulering van crowdfunding is thans een diffuus web van wet- en regelgeving. Op dit moment is er geen specifiek op crowdfunding toegesneden toezichtrechtelijk kader. Op korte termijn hoeft dit ook nog niet te worden verwacht. De in deze bijdrage besproken knelpunten verdienen een oplossing. Hoewel het Wijzigingsbesluit een tweetal knelpunten heeft proberen weg te nemen, heeft het andere problemen ongemoeid gelaten. Dit heeft als gevolg dat de regulering van de crowdfundingsector zowel voor marktpartijen als voor toezichthouders een onoverzichtelijk en daarmee gecompliceerd geheel blijft. De stap die gezet wordt door wijziging van het Bgfo is positief te noemen. Een aantal problemen is weggenomen. De gezette stap is er echter wel een in de verkeerde richting. Wat het Wijzigingsbesluit doet, is niets anders dan toezichtrecht dat niet past op de crowdfundingpraktijk bijschaven, zodat het enigszins beter past. Het achterliggende probleem, het afwezig zijn van een op crowdfunding toegesneden kader, is hiermee echter niet opgelost. Wenselijk zou zijn om niet de richting te kiezen die met het Wijzigingsbesluit is ingeslagen. Niet pogen om het huidige systeem beter bij crowdfunding te laten aansluiten. Hiermee wordt een meer complex systeem van voorwaarden, uitzonderingen, ontheffingen en vrijstellingen gecreëerd, terwijl ondertussen nog steeds wordt gewerkt met een kader dat niet is ontworpen voor de crowdfundingpraktijk. Mijn voorkeur gaat, gelet op de te verwachten ontwikkelingen, uit naar speciaal voor crowdfunding geschreven wet- en regelgeving. De regulering richt zich hierin slechts op de platforms, en wordt opgehangen aan definities van de verschillende varianten van crowdfunding. Op deze wijze kan de reguleringswens het beste in vervulling gaan.

\section{Noten}

1 Zie bijv. brieven van de minister van Financiën van 8 september 2014 met kenmerk DGBI-O/14137149 en van 31 maart 2015 met kenmerk FM/2015/371 M, Kamerstukken II 2014/15, 31311, 145, Kamerstukken II 2012/13, 32013, 35, AFM, Reglementair kader voor crowdfunding (FSMA_2012_15 d.d. 12 juli 2012) en AFM, Crowdfunding - naar een duurzame sector, december 2014.

2 AFM 2014, p. 9-10 en Z. Zhang, R. Wardrop, P.R. Rau \& M. Gray, Moving mainstream. The European alternative finance benchmarking 
report, februari 2015.

3 AFM 2014, p. 12.

4 C.M. Grundmann-van de Krol, Crowdfunding. Hoe, waarom en regulering, in: T\&C Ondernemingsrecht effectenrecht, Deventer: Kluwer 2013, p. 495-496; C.M. Grundmann-van de Krol, Crowdfunding. Een reguleringszoekplaatje?, in: T\&C Ondernemingsrecht effectenrecht, Deventer: Kluwer 2012, p. 141-142; C.J. Noordam, Crowdfunding: een nieuw, maar niet minder risicovol alternatief, FIP 2014, p. 176; J.M. van Poelgeest, Crowdfunding alternatief voor bankfinancieringen?, JBN 2012/49, p. 6-9; J.M. Poelgeest, Crowdfunding, mede mogelijk gemaakt door de wetgever?, O\&F 2014, afl. 4, p. 38-61.

5 Volledig: Besluit tot wijziging van het Besluit gedragstoezicht financiële ondernemingen Wft, het Besluit bestuurlijke boetes financiële sector en enige andere besluiten op het terrein van de financiële markten (Wijzigingsbesluit financiële markten 2016).

6 Noordam 2014, p. 176; DNB en AFM, DNB en AFM oriënteren zich op 'Crowdfunding', <www.dnb.nl/nieuws/nieuwsoverzicht-enarchief/persberichten- 2011/dnb251580.jsp>; AFM 2014.

7 AFM, Q\&A bij nieuwsbrief Crowdfunding, december 2015.

8 Poelgeest 2014, p. 41.

9 Poelgeest 2014, p. 44.

10 Poelgeest 2014, p. 44-45.

11 AFM 2014; Poelgeest 2014; Grundmann-van de Krol 2012.

12 Poelgeest 2014, p. 45-46.

13 Zie hier een verschil met doneren of reward-based crowdfunding, waar de gelden niet hoeven te worden terugbetaald, waardoor ze buiten de reikwijdte van deze verbodsbepaling vallen.

14 Poelgeest 2014, p. 46.

15 M. van Eersel, Crowdfunding. Juridische aspecten van financiering door de menigte, Zutphen: Uitgeverij Paris 2015, p. 36.

16 Van Eersel 2015, p. 33.

17 Van Eersel 2015, p. 34. 
18 Art. 4:3 lid 4 Wft.

19 AFM 2014.

20 Ook voorschriften ten aanzien van geldgevers komen voor. Een consument mag bijv. niet meer dan EUR 40.000 uitlenen en niet meer dan honderd overeenkomsten aangaan per platform.

21 Poelgeest 2014, p. 48-49.

22 Zie art. 1:102 jo. art. 1:105 Wft.

23 In die gevallen dat er beroeps- of bedrijfsmatig geld wordt aangetrokken via een platform.

24 Zoals hierboven reeds is uiteengezet: art. 4:3 lid $4 \mathrm{Wft}$.

25 AFM 2014, p. 33.

26 Nota van toelichting bij het Besluit van de Minister van Financiën tot Wijzigingsbesluit financiële markten 2016 (Conceptregeling 31 maart 2015, <www.internetconsultatie.nl/wijzigingsbesluitfm2016>).

27 Art. 3:10 jo. art. 3:17 Wft.

$\mathbf{2 8}$ Zie het nieuwe art. 2a Bgfo, zoals geïntroduceerd in het Wijzigingsbesluit.

29 Zoals reeds opgemerkt in de internetconsultatie bij het Wijzigingsbesluit.

3o Nota van toelichting bij het Besluit van de Minister van Financiën tot Wijzigingsbesluit financiële markten 2016 (Conceptregeling 31 maart 2015, <www.internetconsultatie.nl/wijzigingsbesluitfm2016>).

31 Nota van toelichting bij het Besluit van de Minister van Financiën tot Wijzigingsbesluit financiële markten 2016 (Conceptregeling 31 maart 2015, <www.internetconsultatie.nl/wijzigingsbesluitfm2016>).

32 Geldvoorelkaar, Crowdaboutnow en Symbid.

33 Nota van toelichting bij het Besluit van de Minister van Financiën tot Wijzigingsbesluit financiële markten 2016 (Conceptregeling 31 maart 2015, <www.internetconsultatie.nl/wijzigingsbesluitfm2016>).

34 Zie par. 3.2.

35 Zoals reeds terecht opgemerkt in de internetconsultatie van het 
Wijzigingsbesluit.

36 AFM 2014, p. 41.

37 Zie art. 3 Vrijstellingsregeling Wft.

$38 \mathrm{Zie}$ art. 2:80 Wft.

39 Nieuwsbrief AFM 'crowdfunding', 11 juni 2015 en bijbehorend stappenplan 'Wanneer heeft $\mathrm{u}$ een vergunning nodig voor crowdfunding?'

40 Van Eersel 2015, p. 50.

41 Poelgeest 2014.

42 Zowel in de matchingsfase als bij de administratie en uitvoering na het sluiten van de overeenkomst.

43 Poelgeest 2014.

44 Richtlijn 2007/64/EC.

$45 \mathrm{PbEU} 2014, \mathrm{C} 300$.

46 Opinion of the European Banking Authority on lending-based crowdfunding (EBA/Op/2015/o3).

47 ESMA's Advice on Investment-Based Crowdfunding, ESMA/2014/1560 en ESMA's Opinion on Investment-Based Crowdfunding, ESMA/2014/1378.

48 Nota van toelichting bij het Besluit van de Minister van Financiën tot Wijzigingsbesluit financiële markten 2016 (Conceptregeling 31 maart 2015, <www.internetconsultatie.nl/wijzigingsbesluitfm2016>).

49 AFM 2014, p. 13.

50 Zoals reeds opgemerkt in de internetconsultatie bij het Wijzigingsbesluit.

$\mathbf{5 1}$ Zoals reeds opgemerkt in de internetconsultatie bij het Wijzigingsbesluit.

52 Zie het stappenplan van de AFM:

$<$ www.afm.nl/nl/professionals/diensten/starters/wetregelgeving/crowdfunding.ash $x>$. 
53 Zhang e.a. 2015.

54 In de periode $2012 \mathrm{t} / \mathrm{m} 2014$.

55 Over de periode van 2012 t/m 2014.

56 Zhang e.a. 2015.

57 AFM 2014.

58 Van Eersel 2015, p. 29.

59 Van Eersel 2015, p. 29.

60 Zo zal financieren door middel van crowdfunding niet onder het depositogarantiestelsel vallen.

$\mathbf{6 1}$ Zoals reeds opgemerkt in de internetconsultatie.

62 Zhang e.a. 2015.

63 Gelet op de reguleringswens als besproken in par. 3.5 en 4.2.

64 Het in detail bespreken van de mate van regulering die per definitie zou moeten worden toegepast, gaat de omvang en strekking van deze bijdrage te buiten.

(C) Boom juridisch 